\title{
AZ EGYEDÜLI ÁLLANDÓ A VÁLTOZÁS: KÉSZEK VAGYUNK-E ARRA, HOGY MI LEGYÜNK A JÖVÖ KÖNYVTÁROSAI?
}

\section{ULRIKE LANG}

\section{Tartalmi összefoglaló}

Milyen változásokat várhatunk a könyvtárakban a következö években? Hogyan kell majd megváltozniuk a könyvtárosoknak, és milyen készségeket kell megszerezniük vagy önmaguknak kifejleszteniük? Személyes nézetek arról, mi fogja újra értelemmel megtölteni pályafutásunkat, átláthatóvá és életképessé tenni szakmánkat.

https://doi.org/10.46280/KOMPKONF.2020.Lang1

„Nem a legerösebb faj lesz a túlélö, nem is a legintelligensebb, hanem az, amelyik a leggyorsabban képes változni." (Charles Darwin)

Tisztelt olvasó! Azért választotta a könyvtáros szakmát, mert szeret olvasni?

Van-e ideje manapság munkaidő alatt olvasni? És olyan témákról olvas-e, amelyeket szeret, vagy inkább „igazgatásról, statisztikáról és pénzügyekről szóló dolgokat”, amelyeket rendszeresen át kell néznie, hogy lépést tartson legfontosabb feladataival? Nem látom, mit válaszoltak erre, de azt hiszem, fontos, hogy képesek legyünk olvasni, bár az egyáltalán nem számít, szeretünk-e olvasni vagy sem.

Ugyanez a helyzet azokkal a készségekkel és tudással, amelyekkel ma és a közeljövőben rendelkeznünk kell, amit munkaadóink és használóink elvárnak tőlünk. A dolgunkat nem szeretnünk kell, hanem el kell végeznünk. És az olvasás szeretetét, mint készséget soha sem várták el a könyvtárosoktól.

Egy példát hoznék arra, hogy mi változott a tudományos könyvtárakban; szeretnék itt egy linket közreadni: https://blog.sub.uni-hamburg.de/?p=8009. Ez a rövid videó a hamburgi Tartományi és Egyetemi Könyvtárban készült néhány éve, amikor igyekeztek megszabadulni attól a könyvtárképtől, amely az utóbbi évtizedben kísérte müködésüket.

A videó nagy ellenkezést váltott ki, különösen a német kollégák körében, és ilyen kérdéseket vetett fel: „Tényleg azt akarjátok, hogy a látogatók a könyvtárban aludjanak, egyenek, igyanak és átrendezzék a bútorokat?” Igen, néhány területen átrendezhetik a bútorokat csoportmunkához, és igen, étkezhetnek és ihatnak is a könyvtárban. Csak a régi és egyedi gyüjtemények olvasótermeiben van olyan korlátozás, hogy az olvasók csak palackozott vizet vihetnek be magukkal. De legyünk őszinték! Tudjuk-e ellenőrizni, hogyan bánnak otthon az 
olvasók a kikölcsönzött dokumentumokkal? Miért vagyunk hát ilyen szigorúak a könyvtári terekben?

Tehát ez a kis videó nem is olyan rendkívüli, mint amilyennek első pillantásra látszik. De bemutat valamit, ami fontosabb. A könyvtár maga változott meg. Nemcsak a munkatársak, hanem a belső tér és a szabályok is. Elmúlt már az az idő, amikor a könyvtáros csak egyetlen mozdulatot tett: a mutatóujját szájához emelve intett a csendre. A könyvtár ma már modern találkozóhely és a tanulás színtere.

Németországban a könyvtárost régóta elöítéletek kísérik, idős hölgyként ábrázolják, aki szemüveget hord és kontyot visel. Át kell alakulnunk: a könyvtáros legyen egyfajta szuperlány vagy szupersrác, aki naprakész az összes technikai eszközben és teendőben, biztonságban érzi magát a digitális korszakban, és képes felmérni a jövőbeli igényeket már, akkor is, amikor még fel sem bukkantak a láthatáron.

Amikor a jövő szuperkönyvtárosát keressük, a következő kifejezésekkel találkozunk:

- mediátor

- átalakítja mások életét

- képes állandóan alkalmazkodni

- társadalomtudós/közgazdász

- elemzi a trendeket és a pénzügyi fejleményeket

- médiaszakértő (hírek, fotók, közösségi média)

- technikai guru

- rendkívül sokoldalú

- kapcsolati szakértő / PR szakértő / marketingzseni

- belsőépítész

Tükrözik-e ezek a feladatkörök azt, amit manapság végzünk, vagy attól félünk, hogy ezek lehetnek feladataink a jövőben?

Természetesen nem mindenkinek lesz ugyanaz a feladata, és természetesen nem mindenkinek, hanem saját magunknak kell a változások érkezésére felkészülnünk. És ez nem lesz lehetséges anélkül, hogy gondosan kialakítanánk az egyensúlyt a könyvtárosok élethoszszig tartó tanulása és az igények figyelemmel kísérése, valamint a legkülönbözőbb életkorú olvasók kérdéseinek megválaszolásához szükséges empátia között.

Az európai országok kétharmadában és a világ néhány más országában is van könyvtári törvény, és müködik országos könyvtári rendszer. Németországban az oktatás és a kultúra - köztük a közkönyvtárak és a tudományos könyvtárak ügyei - szövetségi vagy tartományi hatáskörbe tartoznak; néhány tartományban van könyvtári törvény, de egyelöre csak néhányban. A többieknél előfordulhat, hogy minden fontosabb, mint a könyvtárak, s ez pénzügyi megszorításokhoz vagy az intézmények bezárásához vezet, ha a szövetségi kormány mást tart fontosabbnak.

Tehát nyitottnak kell lennünk a változások iránt, és hajlandónak arra, hogy aktívan, magunk hozzuk létre a változást. A társadalomban folyamatos vita zajlik arról, kik a változó 
társadalmak nyertesei és vesztesei. Nekem meggyőződésem, hogy csak az aktív szereplők, az „alkotók” lesznek a nyertesek.

A könyvtárak számára az egyik kihívás, hogy az egész közösség találkozóhelyeinek kell lenniük. Például az a tartományi és egyetemi könyvtár, ahol dolgozom, nemcsak az egyetemi hallgatóknak és az egyetemi dolgozóknak szolgáltat, hanem mindenkinek, aki olvasni vagy tanulni szeretne; nem számít, miért és mikor. Nálunk a nyitva tartási idő hétfőtől péntekig reggel 9-től éjfélig tart, szombaton és vasárnap pedig 10-től éjfélig. És természetesen van olyan felvetés, miért zárunk be ilyen korán, mert az olvasók közül néhányan szeretnék, ha a hét hét napján, naponta 24 órát lennénk nyitva. De a könyvtárunk a hétvégeken szinte az egyetlen olyan intézmény, amelybe szabad a belépés, ahol fütés és kényelmes ülőhelyek állnak rendelkezésre. Természetesen jönnek a hajléktalanok is, de amíg dokumentumainkat arra a célra használják, amire azok valók, részünkről ez rendben van. És természetesen, amíg másokat nem zavarnak viselkedésükkel vagy mosdatlanságukkal.

Németországban manapság egy hatalmas használói csoport jelent meg a könyvtárakban, a menekültek, akik többnyire nem beszélnek kielégítően németül. Ennek ellenére igyekeznek újra kapcsolatba lépni az egyetemi közösséggel, és minél előbb megtanulni a nyelvet, hogy folytatni tudják egyetemi tanulmányaikat. Szinte a semmiből hoztuk létre könyvtári orientációs programunkat, amelynek keretében - angol nyelven - bemutatjuk a könyvtár szolgáltatásait, csoportos vezetéseket tartunk és - a menekültek státuszától függően - kölcsönzési lehetöséget biztosítunk számukra olvasójeggyel. Arab-német nyelvtanfolyamok anyagát szereztük be, hogy kielégítsük az igényt. Hogy ezt miért említem itt? Mert véleményem szerint a könyvtárosok számára sürgősen elsajátítandó készségek egyike a kreativitás és az azonnali változtatás.

\section{Első készség: kreativitás és azonnali változtatás}

Kreatívnak kell lennünk abban a tekintetben, hogy új partnereket - óvodákat, iskolákat, tanulási és/vagy közösségi központokat, egészségügyi intézményeket stb. - találjunk a helyi és regionális közösségben, mert bizonyos feladatokat nem egyedül végzünk. Ez talán nem új kihívás a közkönyvtárak számára, viszont új feladat a tudományos könyvtárakban.

De mindig meg kell próbálnunk, hogy mi álljunk e feladatoknál a dolgok élén.

Kreatívnak kell lennünk a finanszírozási források megkeresésénél is. Emlékszem azokra az időkre, amikor világos volt, ki fizeti a könyvtár költségeit. Rögzített költségvetéssel dolgoztunk, amelyet évente kellett elkölteni. Ma sokféle lehetőség nyílik arra, hogy bevételünket kiegészítsük európai uniós pénzekből vagy más, harmadik fél pénzalapjaiból, különleges események vagy különleges dokumentumok esetében szponzori támogatásból, amit például a könyvtár baráti köre vagy egy helyi üzleti partner biztosít. Néha a könyvtárak jogi státusza is megváltozott, ezáltal nagyobb szabadsághoz jutottak, hogy kreatívak legyenek, és hogy maguk legyenek felelősek az intézmény finanszírozásáért. Megváltoztak tehát a könyvtárosok 
lehetőségei, és nyitottnak kell lenniük ahhoz, hogy a piacon megtalálják azokat, akikből a legjobb támogatóik lesznek. Könyvtárosokból marketing- és PR-specialistákká kell válniuk.

Egy másik változás a digitális átalakulás, ami nagy esélyt jelent tudástársadalmunk számára és a könyvtárosok számára is. Néhány kollégánk aggódhat amiatt, hogy a jövő könyvtárában nem lesznek már könyvek, csak online dokumentumok, és esetleg nem lesz szükségünk ezekre a hatalmas épületekre és a temérdek raktárra. De nézzük csak végig a további készségeket, azok költségeit és a szükséges tereket, amelyek a könyvtáraink bővítéséhez szükségesek, és gondolkodjunk el azon, valóban csak az épületekre van-e szükségünk.

\section{Második készség: aggregálás}

Napjainkban több könyv és cikk jelenik meg, mint valaha is a történelem során. Természetesen a könyvtáraknak vannak nagyhatalmú versenytársai, mint például a Google, amely „a világ legnagyobb könyvtárát építi fel”, amikor befejezi szkennelési projektjét. Ott van még az Amazon, amelytől a könyvtárosok már megtanulták, hogy katalógusaikat címlapmásolatokkal vagy összefoglalók közlésével egészítsék ki, és hasonló információkat közöljenek. És ne feledkezzünk meg a nagy kiadóvállalatokról. A tudományos életben az aggregálási funkciót a nagy tudományos kiadók és az általuk elöállított adatbázisok veszik át, egysorban a Google Scholar és a Google Books szolgáltatásokkal. Érdeklik-e őket viszont a nem hagyományos és a saját kiadásban megjelenő müvek vagy a nyílt hozzáférés is?

Tehát szükség van valakire, aki figyelemmel kíséri mindezeket az információkat, áttekinti és átválogatja a kiadványtermést, és egyben mutatja be, hogy az érdeklődők megtalálják, ami érdekli őket. Hagyományosan ez volt és ma is ez a könyvtárak szerepe. Ahogy a tartalom előállítása mindenki számára elérhetővé válik, az információk gondozása egyre inkább kritikus alapkészséggé válik.

\section{Harmadik készség: kurátori feladatok}

A tartalommal kapcsolatos kurátori feladatokat így határozhatjuk meg: „olyan egyének tevékenysége, akiket azzal biztak meg, hogy megtalálják, összefüggéseikbe helyezzék és megszervezzék az információkat, megbizható kontextust és architektúrát adjanak hozzá ahhoz a tartalomhoz, amelyet felderitenek és megszerveznek".

A könyvtárosok egyre inkább létfontosságú szerepet kezdenek játszani az értékelési és szerkesztési folyamatban, ők állapítják meg, mi az értékes, ők végzik el azt a kategorizálási és osztályozó munkát, amely a könnyü visszakeresést és használatot biztosítja. Ugyanezt végeztük a múltban is, és ezt kell majd tennünk a jövőben is.

A múltban a tudást és a tényeket például a dokumentumokban, könyvekben és folyóiratokban rögzítettük. Ehhez nem állt rendelkezésre túl sokféle technológia. Azóta tudásunk, 
dokumentációs eszközeink és a technika is fejlődött, és a kurátori feladatok jelentősége megnövekedett.

A digitális korszakban egyre inkább hozzáférhetők az információk, de az információ lehet kétes eredetü, valamint sok információ csak pénzért érhető el. A könyvtárosnak tehát képesnek kell lennie arra, hogy az érdemi információkat az egyes témákban kutatás révén hatékonyan kinyerje, azokat átszűrje és ellenőrizze annak érdekében, hogy értékelje jelentőségét és relevanciáját az intézmény és a használók szempontjából. Ezután az adatokat kategorizálni kell, besorolni különböző témákba és tárgykörökbe, még mielött könnyen érthető és felhasználható formában olvasóink rendelkezésére bocsátanánk őket.

\section{Negyedik készség: tájékoztatás}

Amikor segítünk megkeresni bizonyos tényeket, számadatokat és más információkat a hatalmas dokumentumhalmazban, amelyben weboldalak, blogok, tweetek, videók stb. is vannak, és rendezzük őket, hogy megfeleljenek a speciális igényekkel rendelkező speciális felhasználónknak, az természetesen tájékoztatást jelent, ami a könyvtár igencsak hagyományos funkciója.

Panaszkodhatunk, hogy a kurátori feladatokat maguk az aggregátorok végzik el, tudósok, akik kutatásuk során cikkeket tekintenek át és idéznek, továbbá szorgalmas olvasók ezrei, akik ismertetéseket írnak és jegyzékeket készítenek. Eközben a Google keresőmotor és a wikipédia már learatta és begyüjtötte a könyvtári tájékoztató szolgálat mindegyikét.

De a könyvtáraknak, ahol jól képzett könyvtárosok dolgoznak, még vannak jelentős előnyeik.

Először is az, hogy a használó érdekében, az ő számára dolgozunk. Míg legtöbb konkurensünket a profit motiválja, első és legfontosabb szakmai kötelességünk, hogy használóink információs és olvasás iránti igényeit kielégítsük.

Másodszor: hosszú évszázadok óta kínáljuk a tudást és a tapasztalatokat. Ismerjük a forrásokat és azok értékelési módját. És mivel évek óta készítünk referensz-interjúkat, tisztában vagyunk azzal, hogyan tudjuk kideríteni, valakit mi érdekel, még akkor is, ha maga sem tudja, vagy nem képes kifejezni azt.

És megvan a hírnevünk. A könyvtáros szó és a hozzá kapcsolódó imázs elválaszthatatlanul összekapcsolódik a könyvekkel, olvasással, információval, a tudásszomjjal és a szellemi élettel. Dolgoznunk kell e célok elérése érdekében, de arról is ismernek bennünket, hogy megvédjük az emberek jogát arra, hogy azt olvassanak, amit szeretnének, és hogy zavartalanul élhessenek ezzel a jogukkal. Ez pont annak a személyiségtípusnak a képe, akitől azt várjuk, hogy segítsen nekünk navigálni az információk elektronikus óceánján. Vannak olyan erős és versenyképes előnyök, amelyeket a könyvtárosok hozhatnak be az információs piactérre.

A verseny elvezethet majd ahhoz, hogy be kell zárni az épületeket és csökkenteni kell a személyzetet, s a könyvtárakban már nem lesznek könyvek és más nyomtatott dokumentumok.

De mindez igen furcsán zajlik. Egyes szakértők a könyv reneszánszáról beszélnek, míg mások a nyomtatott dokumentumok végéről nyilatkoznak. Amikor az e-könyvek megjelentek a palettán, nagy fellendülés indult, ez mára csökkenni látszik. Minden forgatókönyvre 
fel kell készülnünk. Régebben a másológépeink soha nem voltak ennyire igénybe véve, mint ma: a diákok minden digitális dokumentumot kinyomtatnak, amelyre szükségük van, mert szeretnek a papíron jelölgetni és észrevételeket tenni ahelyett, hogy az adatokat a laptopjukon vagy a felhőben tartanák.

A digitalizálás során a könyvtárosoknak tudniuk kell azt is, hogyan őrizzék meg és kezeljék a digitális adatok valamennyi formáját. Ismerniük kell a különböző rendszereket és eszközöket, amelyeket e folyamat során használnak, de rendelkezniük kell a fizikai források megőrzésével kapcsolatos tudással is, mivel ezek továbbra is velünk élnek.

Használóinknak szükségük van a könyvtárosokra és a könyvtárakra a csoportmunka és az online dokumentumokhoz (például a licencelt adatbázisokhoz) való kapcsolódás vagy a távtanulási lehetőségek támogatásának helyszíneként. A könyvtárosoknak aggregálniuk (gyüjteniük) kell ahhoz, hogy a használókat elirányítsák a lehető legjobb információforráshoz, amelyet szeretnének, tekintet nélkül arra, hogy az hol található. Figyelemmel kell kísérnünk az internetes kurátorok munkáját, és el kell végeznünk a tájékoztatómunkát, ha a Google keresőmotorja vagy a használó nem jár sikerrel. A teljesen elektronikus könyvtárra áttérve élvezhetjük a web eszközeit és előnyeit. És más könyvtárakkal együttműködésben ismét például a licencekkel vagy virtuális tájékoztatópultokkal dolgozva - ésszerüsíthetjük és hatékonnyá tehetjük szolgáltatásainkat. És pénzt takaríthatunk meg. Nagyon népszerütlen az a nézet, hogy a jövőben talán kevesebb könyvtár lesz a digitális világban, mint ma. De úgy vélem, megvan a lehetőségünk arra is, hogy a könyvtár olyan hellyé váljon, ahol előadásokkal és a szerzőkkel való találkozókkal inspirálhatjuk használóinkat.

Beláthatjuk, hogy a könyvtári munkaterületek már meg is változtak. Mi történik majd azokkal a kollégákkal, akik például azért vesztették el munkájukat, mert RFID-eszközöket helyeztek üzembe a könyvtárban?

Hogyan tudunk számukra új feladatokat találni, még mielőtt egy robot átveszi tőlük azokat a feladatokat, hogy leszedik a könyveket a polcokról és visszarakják azokat? Ha még lesznek könyvek, és valaki beléjük akar nézni.

Hamburgban mostanában igyekszünk ezeknek a kollégáknak új feladatkört találni továbbképzéseket biztosítva számukra, amelyek témája az ügyfelek segítése vagy a digitalizálási folyamatot segítő technikai eligazítás, de az is biztos, hogy a jövőben kevesebb olyan munkatársat alkalmazunk, akinek nincs könyvtárosi végzettsége.

Meggyőződésem továbbá, hogy a könyvtárosok fontos készsége jelenleg és a jövőben is a szórakoztatás.

\section{Ötödik készség: szórakoztatás}

Természetesen nem kell a szórakoztatást hivatásnak tekinteni (hacsak nem gyerekprogramokkal foglalkozunk), de úgy gondolom, hogy egy könyvtárosnak, aki visszahúzódó természetű, nehéz lenne egy könyvtárban dolgoznia. Meg kell változtatnunk a társadalom könyvtárosképét, ahogy már korábban jeleztem, mégpedig azért, hogy úgy tartsák őket számon, 
mint akik az ügyfelek/használók modern és a technika iránt affinitást mutató támogatói. Ahhoz, hogy másnak lássanak bennünket, a Google és a használók okostelefonjain lévő alkalmazások használatán túlmenően is különlegesnek kell lennünk, hogy vonzzuk a használókat, különösen a fiatalokat és az újakat. Használjuk a Prezit, a HaikuDecket, a SlideDogot, a Google Slidest vagy - Apple használóként - a Keynote-ot a Powerpoint helyett, mégpedig hamarabb, mint a könyvtárhasználók. Legyünk a haladás élharcosai, ne pedig kései követői!

A mobil környezet ismerete igen lényeges. Mivel egyre több információt tárolnak a felhőben, és keresnek ki és fogyasztanak mobil eszközöket használva, a könyvtárosoknak jól kell ismerniük és érteniük a mobil környezet csínját-bínját. Készségszinten kell használniuk a tableteket és okostelefonokat ahhoz, hogy biztosítani tudják, hogy információs rendszereik és portáljaik megfeleljenek a használók igényeinek. Értenünk kell a felhőalapú számítástechnika mellett és az ellene szóló érveket, hogy tanácsadókként és konzultánsokként tudjanak müködni a különböző információs kurátori és digitális megőrzési feladatokkal kapcsolatos döntéseknél.

A hamburgi Tartományi és Egyetemi Könyvtár volt az első német könyvtár, amely létrehozott egy közösségimédia-menedzseri munkakört. Az illető munkatárs felel különböző, külső és belső blogjainkért, FB-oldalunkért, szereplésünkért a Twitteren és az Instagramon, és természetesen azért, hogy rendszeresen ellenőrizze a weben, milyen újdonságok és fontos fejlemények vannak az új technológiák területén, amelyek a használók javára hasznosíthatók. Keresi a könyvtár említéseit is, és szükség esetén kommenteket is írhat.

Néhány esetben nem is vagyok biztos benne, hogy használóink is már olyan mértékben megváltoztak, mint a könyvtárosok. De ismétlem: nekünk kell kitaposni az ösvényt!

A könyvtárban én vagyok felelős a könyvtárkezelőkért, s éves értékelésük során mindig megkérdezem tőlük, milyen közösségimédia-csatornát használnak és milyen könyveket olvastak. Aztán megkérdezem a véleményüket arról, hogy szerepeljenek-e a könyvtárak a közösségi médiában. És furcsa módon - bár a közösségi média több csatornájára fel iratkoztak - úgy vélik, a könyvtáraknak nincs szükségük Facebook-oldalakra, Twitterre vagy Instagramra. De olvasóink használják őket. Úgyhogy természetesen ott kell őket „elkapni” a helyszínen, és többé már nem kell rendszeresen levélben vagy levelezőlapon megkeresnünk őket.

Élnünk kell a számunkra ma elérhető eszközökkel és technológiákkal, hogy jobb és hatékonyabb módszerekkel kapcsoljuk össze az embereket a könyvekkel és információkkal.

\section{Hatodik készség: az emberi erőforrások másfajta kezelése}

Engedjék meg, hogy kis kitérőt legyek, és megemlítsek néhány fontos készséget, amelyekre szerintem szükség van társadalmunkban, és amelyek nem csak a könyvtárakban jellemzőek. Ezek egyrészt a munkaszervezéssel, másrészt a hierarchiák kezelésével kapcsolatosak. De természetesen csak a németországi munkafeltételekről tudok nyilatkozni.

Remélem, hogy olyan kultúrát tudunk létrehozni, amelyben a vezetők egyfajta trénerként (coachként) müködnek az adott csoportban. Már nem az eredményekért és a teljesítményért 
felelősek, hanem a pénzügyi és emberi eröforrások biztosításáért, annak érdekében, hogy a munkatársak maguk érjék el céljaikat. Németországban is sokszor dolgozunk a hibák elhárításán, amikor például „az elkövetőt keressük”. Remélem, hogy ennél jóval termékenyebb és szakmaibb átalakulást tudunk elérni, azzal foglalkozva, hogy „hol a megoldás”, és hogyan hozhatjuk ki a legjobbat az adott helyzetből.

Egy másik probléma a szakma és a család összhangja, ami az utóbbi években igen aktuális témává vált Németországban. Ha vannak jól képzett munkatársaink, akik jobb szakmai készségekkel rendelkeznek, ők dolgozhatnak otthonról, mert ahhoz, hogy kreatívan és hatékonyan dolgozzanak, csak a fejükre és egy internetkapcsolatra van szükség. Az alulképzett munkatársak rendszerint olyan feladatokat kapnak, amelyeket bent a könyvtárban kell elvégezniük.

Tehát lehetséges, hogy kevesebb munkatársra lesz szükségünk, ugyanakkor problémát jelent az új munkatársak toborzása. A babyboom- és az X generáció után mostanában az Y generáció fiatalabb évjáratait, a digitális bennszülötteket alkalmazzuk. És eközben továbbra is vonzóaknak kell lennünk az új munkatársak számára. Ezért rugalmas munkaidőt vezettünk be, összhangban azzal, hogy a munkatársaknak időre van szükségük ahhoz, hogy gyermekeikkel vagy gondozást igénylő, idősebb családtagjaikkal törődjenek.

És el kell gondolkodnunk olyan modelleken, amelyeknél a munkatársak bizonyos időpontokban nem érhetők el munkahelyi ügyekben. Ezt néha valóban nehéz biztosítani, mert ma már mindig el tudjuk érni munkahelyi e-mailjeinket okostelefonunkon, de a probléma nem hanyagolható el a munkatársak egészsége, az irántuk érzett felelösség miatt. A jelenlegi kutatások azt mutatták, hogy a fiatal generáció igen nagy érdeklődést mutat aziránt, hogy a munka és a szabadidő legyen egyensúlyban. A vezetők esetleg nehezen tudják eldönteni, hogy mi a fontosabb egy intézmény számára, az eredmények vagy a munkatársak egészségének menedzselése. Az új munkatársak toborzása mutatja meg majd a jövőben, melyik irányba billenti a piac ezt a mérleget.

És ebben a fajta munkaszervezetben sürgősen szükségünk van kommunikációs készségekre.

\section{Hetedik számú készség: kommunikáció}

Hol tanultuk meg azt a képességet, hogy megfelelő módon kommunikáljunk kulturális, politikai és külső környezetünkkel? Nemcsak a különböző felhasználói csoportokkal, hanem a különböző munkatársakkal, a költségvetésünket befolyásoló emberekkel, politikusokkal stb., és természetesen a saját környezetünkkel létesített kontaktus során, akikkel nap, mint nap kommunikálnunk kell.

Öszintén szólva, amikor könyvtári tanulmányaimat végeztem, még nem vettem részt kommunikációs készségfejlesztő kurzusokon, sőt a fönököm sem. Nem elég ezt a gyakorlatban megtanulni. A munkatársak számára fontos ilyen kurzusokat kínálni, ahol esetleg más címen sajátíthatják el a szükséges készségeket (pl. kommunikáció a problémás használókkal, vagy csoportkommunikáció). 
Meggyőződésem szerint sokkal többet kell foglalkoznunk az egészség kérdésével. Még emlékszem azokra az időkre, amikor a munkatárs maga volt felelős azért, hogy munkaképes állapotban legyen. Szabadidejében kellett regenerálódnia. Napjainkban, amikor nincs elegendő fiatal munkatársunk, másnak kell lennünk, mint a versenytársainknak. Adjunk lehetőséget munkatársaink számára, hogy a munkaidőben felfrissüljenek, például úgy hogy szünetet biztosítunk, amikor mozoghatnak, rövid masszázst biztosítunk nekik, vagy másféle regenerálódási lehetőséget, például izomlazító tréninget stb. Adjunk alkalmat a tanulásra. Az élethosszig tartó tanulás nemcsak használóink számára jelent feladatot, hanem nekünk és munkatársainknak is.

Ahhoz, hogy megbecsült és fontos információs szakemberekké válhassunk, és voltaképpen már azok is lettünk, nézetem szerint igen fontos, hogy befogadjuk ezeket a készségeket, amelyek újra értelemmel töltik meg pályánkat, átláthatóbbá és életképesebbé teszik szakmánkat.

Idézettel kezdtem, azzal is fejezem be: „Te magad légy a változás, amit látni szeretnél a világban." (Mahatma Gandhi)

Ulrike Lang a hamburgi Carl von Ossietzky Tartományi és Egyetemi Könyvtár (Staats- und Universitätsbibliothek) osztályvezetője. Munkahelyén oktatási és továbbképzési kérdésekkel, konfliktuskezeléssel és egészségügyi prevencióval, egyenlőségi kérdésekkel foglalkozik. A Berufsverband Information Bibliothek (BIB) tagja. 2000 és 2007 között a német könyvtári egyesületek ernyőszervezete (BID) külügyi bizottságának vezetője. Korábban az IFLA Folyamatos Szakmai Képzési és Gyakorlati Képzési Szekciójának (Continuing Professional Development and Workplace Learning Section) egyik alapítója, tagja, 2009 és 2015 között társelnöke, most konzulense. Jelenleg az IFLA Oktatási és Képzési Szekciójának (Education and Training Section) vezetőségi tagja. 